\title{
Intellectual Capital Disclosure Commitment: Myth or Reality?
}

\author{
Deborah Branswijck ${ }^{1}$ and Patricia Everaert ${ }^{2}$
}

\author{
${ }^{1}$ Ghent University College, Faculty of Business Administration and Public Administration, Department of \\ Accounting and Tax, Voskenslaan 270, 9000 Ghent, Belgium \\ Deborah.branswijck@hogent.be \\ ${ }^{2}$ Ghent University, Faculty of Economics and Business Administration, Department of Accounting and \\ Corporate Finance, Kuiperskaai 55/E, 9000 Ghent, Belgium \\ Patricia.everaert@ugent.be
}

\begin{abstract}
The objective of this empirical research is to assess the information dealing with intellectual capital that firms disclose in their prospectus and the potential influence on their intellectual capital disclosure in the annual report following to the initial public offering. The prospectus of companies that applied for initial listing on Euronext Brussels and Amsterdam between 2005 and 2009 were analyzed, including the first annual report after IPO, by means of a content analysis based on the disclosure index of Bukh et al (2005). First, the prospectus and annual report were compared based on their intellectual capital disclosure. Second, the prospectus and the annual report were studied in order to understand the disclosure practices on IC during a 5 year time period taken the recent financial crisis into account. Third, a model was built in order to explain the impact from IC disclosure in the prospectus on the disclosure in the annual report. Next to the result on the IC index for the prospectus (1), different control variables such as (2) industry, (3) company age, (4) size, (5) auditor and (6) ownership retention were added to the model.
\end{abstract}

\section{Keywords}

Initial Public Offering, Intellectual capital, Economic crisis, Content analysis, Disclosure

\section{Introduction}

In recent years, it has been commonly observed that a company's market value is well above its book value. This might suggest that traditional accounting systems deliver a financial statement that does not fully reflect the value relevant information. Previous research has revealed that intellectual capital (IC) or intangible assets (an intellectual capital component) outside the financial statements are the value drivers of firms since they increasingly base their own value on know-how, patents, skilled employees and other intangible assets (Bukh, 2003). The importance of these assets gained the attention of the International Accounting Standards Board. Therefore, they developed an accounting standard on intangible assets (standard IAS 38) which was update in 2008. According to this standard, some IC elements are disclosed in the annual report but most of them still remain undisclosed. Consequently, investors lack information which could result in an increased risk perception. This can cause difficulties in attracting funds and can possibly lead to an underestimation of future earnings (Walker, 2006). In order to avoid this underestimation, companies can decide to voluntarily disclose value relevant information. On the one hand, Cordazzo (2007) found that in the prospectus, companies provide investors with the voluntary disclosure of IC by reporting additional information on the companies' risk, future profitability and strategy. Brüggen et al. (2009), on the other hand, studied the determinants of IC disclosure in the annual report and identified industry and firm size as possible explanatory variables. Since the annual report generally focuses on the historical performance of the company, some differences are likely to be reflected in the nature of IC disclosure between the prospectus and the annual report. It is argued that the quality of reporting in the prospectus could be seen as a role model for future information disclosure of the company (Cumby and Conrad, 2001; Beattie, 1999). However, the question could be asked if companies 
that have a high level of IC disclosure in their prospectus also disclose relatively more in their annual report. In other words, does IC disclosure commitment exist? According to our knowledge, there is no literature on comparing IC disclosure in the prospectus and the annual report. Only a slightly comparable study of Nielsen et al. (2006) indicated similarities between the IC disclosure in the intellectual capital statement and in the annual report.

Sutthachai and Cooke (2009) found that Tai financial reporting disclosure practices increased over time, but the changes in disclosure occurred mainly in the economic crisis period, suggesting that the economic disturbance had an impact on it. Since the financial and economical crisis in 2008 caused a downfall of share prices on all global bourses, it is expected that companies disclose more voluntary information. The capital market-association theory assumes that earnings management and information disclosure have an impact on capital markets and therefore could be linked to an economic disturbance. The crisis could result in more accurate and relevant disclosure concerning intellectual capital in order to convince investors to buy shares from newly listed companies. Based on this outcome, we can investigate whether the recent financial crisis also had an influence on the level of voluntary IC disclosure in the prospectus and the annual report.

\section{Hypothesis development}

Previous studies on IC disclosure in the prospectus used a content analysis to determine whether stakeholder groups, with an interest in controlling certain strategic aspects of the organization, will be informed voluntarily on the company's IC during the initial public offering (IPO) (Bukh et al., 2004 ; Singh and Van der Zahn, 2008). During an IPO the amount of stakeholders of a company increases. The stakeholder theory suggests that an organization's management is expected to undertake activities deemed important by their stakeholders. According to the latter, a company will voluntarily disclose information about its intellectual performance above mandatory requirements in order to meet these expectations (Deegan, 2000). Moreover, the traditional accounting models are unable to reflect the new ways of creating value. The most intuitive measurement of the value of IC is the difference between the net book value and the market value of a company (Holland, 2001). Firms with a great difference between these two measures have a high level of IC. For some companies this difference may come from a brand name for others it may come from know-how or patents. The value of those intangible assets could represent more than $60 \%$ of the business assets (Lev, 2001) and therefore the necessity to voluntarily report about these value creation indicators increases. Since reporting on IC is voluntary, firms will only disclose this information if there are advantages related to. These advantages are, according to Vergauwen and van Alem (2005) and Depoers (2000), among others related to decreasing information asymmetry between the company and the users of financial statements, lower borrowing costs due to a better estimation of the risk associated with the company and a higher value relevance of the financial statements. Furthermore, economic theory suggests that a commitment by a firm to an increased level of disclosure should lower the information asymmetry component of the firm's cost of capital. Leuz and Verrecchia (2000) showed that substantially increased levels of disclosure caused several economic benefits. Based on a sample of German companies, they found that an international reporting strategy (which assumes a commitment towards an increased level of disclosure) is associated with lower bid-ask spreads and higher share turnover. Due the nature of the economic benefits accompanied with it, firms that have undertaken an IPO will continue to disclose more. Therefore, it could be assumed that IC disclosure commitment starts in the prospectus and will be reflected in the subsequent annual report. This results in the following hypothesis

$\mathrm{H} 1$ : A more than average level of IC disclosure in the prospectus results in a more than average level of $\mathrm{IC}$ disclosure in the subsequent annual report due to disclosure commitment.

Previous research on financial reporting (Cooke and Wallace, 1990) revealed that the environment in which the company operates shapes financial reporting practices. According to this legitimacy theory, organizations continually try to operate within the boundaries and norms of their societies. From this perspective, a company would voluntarily report on activities if the management perceived that this was expected by society. These expectations are not fixed but change over time. Consequently, the company needs to be responsive to the environment in which it operates (Deegan, 2000). It is expected that firms are more likely to report on their IC if they find themselves unable to legitimize their status on the basis of the traditionally recognized fixed assets as symbols of corporate success. Since the recent economic 
disturbance changed the environment in which companies operate, the following hypotheses can be formulated:

H2a: The economic disturbance has a positive influence on the voluntary reporting of IC in the IPO prospectus.

$\mathrm{H} 2 \mathrm{~b}$ : The economic disturbance has a positive influence on the voluntary reporting of IC in the annual report.

Daily et al. (2003) suggested that the IPO prospectus is often more precise than other reporting media because companies are liable for any misleading or inaccurate information. It can be observed that the prospectus usually contains more information about future expectations regarding market developments and earnings, strategic direction, management, board composition, etc., compared to the annual report. At the time of admission for listing on the stock exchange the company has to convince future shareholders to invest capital. Mather et al. (2000) found that the firms' management has an incentive to present the company in the best possible light in order to maximize the proceeds of the share issue. Although this could lead to earnings management, the IPO prospectus provides insights into which types of information are selected by a company for representing itself in relation to investors and analysts. In other words, it could be argued that a company sees the prospectus as a publicity brochure in which it reports in detail about its achievements, skills and growth potential. All of these items are related to the intellectual capital of the company. Compared to the IPO prospectus, the annual report has not only investors as its readers but it also conveys information to employees, potential employees, customers, NGOs and other stakeholders. Due to this enlarged group of readers, it is argued that some differences occur in the extent of disclosure in both company documents. As to the annual report, the prospectus can be assumed to provide additional disclosure on the company's long term strategy and risks (Cumby and Conrad, 2001). This results in the following hypothesis:

H3: Companies disclose in general more IC information in the prospectus than in the annual report.

\section{Methodology}

\subsection{Data collection}

Prior literature tends to define IC as non-monetary assets without physical substance, such as innovation, knowledge, research and development, employee training or customer satisfaction, that have an impact on the firm's value (Lev and Zambon, 2003). Based on this definition, IC can be divided into structural capital, organizational capital and relational capital. These subdivisions are also found in the disclosure index of Bukh et al. (2004). Based on the index of Bukh et al. (2004), 74 companies in Belgium and The Netherlands between 2005 and 2009 were coded. The index consists of 86 elements categorized into six subgroups namely 'Employees', 'Customers', 'Information Technology', 'Research and Development', 'Processes' and 'Strategy'. For the subgroup 'Strategy', three items were added namely 'Competitor Names', 'Suppliers' and 'Business Acquisitions'. Furthermore, the subgroup 'Customers' is extended with the items 'Client Name', 'Customer Satisfaction' and 'Customer Knowledge'. Lastly, the items 'Insurance', 'Key Employees', 'Value Added on Employees', 'Employee Attitude', 'Employee Communicative Activities' and 'Expert Teams' were added to the subgroup 'Employees'. These adaptations were based on the differences in indexes used in Bontis (2002), Vergauwen and van Alem (2005) and Beattie and Thomson (2007). Not only the presence or absence of information pertaining to each IC item for a particular company was documented, but also the difference between qualitative and quantitative information was taken into account. On the one hand, Bozzolan et al. (2003) introduced a weighting scheme for their IC disclosure index by counting qualitative disclosures as 1 and quantitative disclosures as 2 . The reason lies in the fact that companies are more likely to be accurate in quantitative disclosure. Guthrie and Petty (2000), on the other hand, highlighted the difficulty in quantifying IC since it is in many instances a qualitative item. For this research the presence of a certain item is coded as 1 if the item is discussed in general, qualitative information specifically described on the selected item is coded as 2 and quantitative information as 3 . The total score on the IC index is calculated as follows:

$$
\text { SCORE }=\sum d_{i}
$$


where $d_{i}$ expresses item $\mathrm{i}_{\mathrm{i}}$ with value 1 if the item $\mathrm{i}_{\mathrm{i}}$ contains general information, 2 if the item $\mathrm{i}_{\mathrm{i}}$ contains qualitative information and 3 if item $\mathrm{i}_{\mathrm{i}}$ contains quantitative information. This index is used to apply a content analysis. The method of a content analysis is a widely used method to quantify the amount of disclosure in company reports (Beattie and Thomson, 2007)

A second researcher independently confirmed the coding of the first researcher in order to maintain consistency in the coding decisions. The prospectus as well as the annual report was analyzed manually for IC information. The annual report regularly contains both mandatory and voluntary information such as the financial statement (balance sheet, income statement, cashflow statement, notes and auditor's report), mission statement, chairman's report and corporate governance. Since there exists no accounting regulation on IC, corporate managers might choose to include IC items that are not reported in the financial statements but in other sections of the annual report in order to stress the importance to the reader. Therefore, every single company report is individually scanned for the list of IC-related terms of the index. Since not all corporate documents were available, the total sample resulted in 65 company prospectuses and 41 annual reports and financial statements. Due to their specific reporting requirements, we decided not to include the banking industry.

\subsection{Control variables}

To formally test whether there exists a disclosure commitment, a number of control variables were included into the analysis. Vergauwen \& Van Alem (2005) found that companies in The Netherlands disclose relatively low on IC in comparison with French and German companies. Another research (Vandemaele et al., 2005) revealed that Swedish companies disclose on average more about IC than companies in The Netherlands and the UK. Based on a previous research (Orens \& Derboven, 2008) of IC disclosure in the prospectus of Belgian companies, which indicated that they do not disclose an elaborated level of IC disclosure, we assume that there are no significant differences between these two countries.

Previous research has often seen company age as a proxy for risk since more established companies are less risky. From this perspective, a company's amount of disclosure is expected to be related to the company age. Amir and Lev (1996) found that non-financial information is of greater importance for the valuation of younger companies. Furthermore, Jaggi (1996) found that the amount of inaccurate information in the prospectus is larger for younger companies. These previous studies might be an indication for a negative relationship between the level of disclosure on IC and company age. Company age is measured as the amount of years the company exists since its foundation. Next to company age, researchers also found a relationship between the level disclosure and company size. Watson et al. (2002) indicate that the cost of voluntary reporting is relatively high for smaller companies compared to the cost for larger ones. Furthermore, larger companies have more to win with an increased level of information since the trading of effects increases due to lower uncertainty. These firms are under the control of the government and an increased level of disclosure can reduce the governmental pressure (Buzby, 1975). Moreover, the need for capital for large companies is higher than for small firms. A lower cost of capital is obtained since the information asymmetry reduces. Based on a directive of Europe (2003/361/EG of the Commission of 6 may 2003) turnover, total assets and amount of employees can be used to determine the size of a company. All of these indicators for size were obtained for each company.

Previous research tried to find a link between the amount of disclosure on IC and the industry to which the company is affiliated. Due to historical reasons some industries disclose more information than others. It is expected that if one company in a certain industry reports voluntarily on a specific topic, other players in the market will also report on that topic. Cooke (1991) found in his study that Japanese production companies disclosed significantly more in their reports compared to other industries. Also Wallace et al. (1994) and Dye \& Sridhar (1995) suggest that the industry in which a company is active will have an influence on the voluntary disclosure behavior. A company that chooses not to disclose on a topic, is seen as a company that wants to hide bad news. The public attention that companies receive will influence the amount of disclosure. Different research has been performed in order to find evidence for this hypothesis. Cooke (1989) used a detailed index for the variable industry that exists out of production, commercial, services and conglomerates in his investigation for Swedish companies. The results indicated that commercial companies report less voluntary information compared to others. The research of Abdolmohammadi (2005) shows that certain industries of the new economy disclose more on 
intellectual capital and information systems compared to mature industries which disclose more on their brands and strategic alliances. The importance of intellectual capital disclosure is found in high-tech industries. Comparing the book value and the market to book ratio of these companies, it could be noticed that the values for IT and biotech companies are generally higher. Bukh et al. (2005) indicate that these companies will report more voluntary information next to the traditional financial reporting. In our study, the construct industry is measured by different dummy variables such as "Chemicals", "Consumer goods", "Industrial goods and utilities", "Financial services" and "IT". These categories are based on the Industry Classification Benchmark (ICB) used by Euronext. Allocation to the appropriate industries in ICB classification system is made in collaboration with the management of the companies. Some industry classes of the ICB system were grouped together to increase the amount of observations for each industry group.

Another variable of interest is audit firm. An audit firm uses its reputation as a competitive advantage. This reputation capital is strongly influenced by accounting scandals. The Enron debacle, for example, showed what can happen to an audit firm involved in such a scandal. Andersen, the audit firm of Enron, went out of business even before a single lawsuit was filed against it. In order to avoid this risk of litigation, auditors prefer financial statements that are stated and audited strictly according to accounting regulations. Because of the vague and contradicting regulations on IC, it could be argued that auditors omit IC-related items out of the financial statements. Therefore, auditor conservatism can be considered to have a prominent influence on the disclosure of IC-related information. Clarskon et al. (2003) found that international accounting firms in particular show conservative auditor behavior. Consequently, the dummy variable "Big4Auditor" was added to the model.

Ownership retention during the IPO could be seen as an indication of the quality of the firm. Since it is costly to retain a significant stake in the firm, a large fractional ownership would preclude the entrepreneur from diversifying his personal investment. Leland and Pyle (1977) constructed a model to predict the behavior of the owner of a company when information asymmetry exists. The model implies that the ownership retention will be high if the owners expect that the firm value is higher than reflected in the financial statements. Consequently, rational investors will perceive ownership retention as a signal of firm value. Furthermore, according to O'Sullivan (2000), we can expect less disclosure from the company if the degree of ownership retention is high. If the directors do not own a substantial portion of the company, it can be expected that they encourage more intensive disclosure in order to fulfill their monitoring role. Therefore, the variable "Ownership" was added to the model.

\subsection{Model}

In this section the defined hypotheses will be tested by means of a linear regression. The independent variable industry will be entered in the equation as several dummy variables. In order to avoid the dummy variable trap, one of the industries, namely "IT" was not included in the regression. Admission of this industry would lead to multicollinearity since there is a linear relationship between the industry-variables (Baker, 2006)

Score_AR $=\lambda_{0}+\lambda_{1}$ Score_IPO $_{j}+\lambda_{2}$ Crisis $_{j}+\lambda_{3}$ Size $_{j}+\lambda_{4}$ Chemicals $_{j}+\lambda_{5}$ Cons_Goods $j+\lambda_{6}$ IndGoods_Utulities ${ }_{j}+\lambda_{7}$ Financial_services $_{j}+\lambda_{8}$ Age $_{j}+\lambda_{9}$ Auditor $+\lambda_{10}$ Ownership $+\mu_{j}$

where:

Score $\_A R_{j}=$ the result on the index for the subsequent annual report after initial public offering

Score_IPO ${ }_{j}=$ the result on the index for the prospectus on the year of initial public offering

Crisis $_{j}=$ a dummy variable equal to 0 for an initial public offering in 2005, 2006 or 2007 and 1 otherwise

$\mathrm{Size}_{\mathrm{j}}=$ the total assets of the company

Chemicals $s_{j}=$ a dummy variable equal to 1 if firm ${ }_{j}$ belongs to that industry and 0 otherwise with IT as a reference category 
Cons_Goods $s_{j}=$ a dummy variable equal to 1 if firm $\mathrm{j}_{\mathrm{j}}$ belongs to that industry and 0 otherwise with IT as a reference category

IndGoods_Utulities ${ }_{j}=$ a dummy variable equal to 1 if firm $\mathrm{j}_{\mathrm{j}}$ belongs to that industry and 0 otherwise with IT as a reference category

Financial_services ${ }_{j}=$ a dummy variable equal to 1 if firm ${ }_{j}$ belongs to that industry and 0 otherwise with IT as a reference category

$A g e_{j}=$ the difference between 2010 and the year of establishment of firm $\mathrm{j}_{\mathrm{j}}$

Auditor $_{j}=$ a dummy variable equal to 1 if firm $\mathrm{j}_{\mathrm{j}}$ is audited by a big 4 company and 0 otherwhise

Ownership $_{j}=$ the amount of shares retained by the owners during the IPO, expressed in percent

\section{Research findings}

\subsection{Descriptive statistics}

Table 2 gives an overview of the different industries and the areas of IC disclosure. A percentage of $33 \%$ in the area costumers (CU) indicates that $33 \%$ of the companies in the chemical industry report on at least one item in the area customers. When taking a closer look at the areas of disclosure, most companies report on human resources (HR) and strategy (ST). Regarding HR, this can be explained by the obligation of companies to deposit a social balance at the national bank of Belgium. This obligation also has an impact on the nature of the information reported on. Furthermore, only $36 \%$ of the companies in the IT industry disclose information related to IT. Noticeable is that, compared to the annual report, companies tend to report in their prospectus on at least one item of the different areas. Furthermore, almost each industry reports about its strategy in its prospectus. Moreover, it could be noted that for each disclosure area there is a possible relationship between the annual report and the prospectus. Areas on which companies disclose much (e.g. HR and ST) are the same for the annual report and the prospectus.

Table 2: Descriptive Statistics for IC disclosure areas per industry

\begin{tabular}{|ll|r|r|r|r|r|r|}
\hline & & HR & CU & IT & PR & RD & ST \\
\hline Annual Report & Chemicals & $89 \%$ & $33 \%$ & $44 \%$ & $44 \%$ & $44 \%$ & $89 \%$ \\
& Consumer Goods & $63 \%$ & $6 \%$ & $0 \%$ & $13 \%$ & $19 \%$ & $44 \%$ \\
& Industrial Goods \& Utilities & $65 \%$ & $41 \%$ & $12 \%$ & $47 \%$ & $35 \%$ & $65 \%$ \\
& Financial Services & $73 \%$ & $45 \%$ & $9 \%$ & $64 \%$ & $18 \%$ & $55 \%$ \\
& IT & $79 \%$ & $71 \%$ & $36 \%$ & $50 \%$ & $64 \%$ & $79 \%$ \\
Prospectus & Chemicals & & & & & \\
& Consumer Goods & $100 \%$ & $70 \%$ & $40 \%$ & $20 \%$ & $80 \%$ & $100 \%$ \\
& Industrial Goods \& Utilities & $100 \%$ & $89 \%$ & $22 \%$ & $33 \%$ & $61 \%$ & $100 \%$ \\
& Financial Services & $100 \%$ & $93 \%$ & $50 \%$ & $50 \%$ & $79 \%$ & $100 \%$ \\
& IT & $90 \%$ & $60 \%$ & $40 \%$ & $30 \%$ & $30 \%$ & $100 \%$ \\
& & $93 \%$ & $93 \%$ & $53 \%$ & $27 \%$ & $87 \%$ & $93 \%$ \\
\hline
\end{tabular}

HR refers to the area 'Human Resources', CU refers to the area 'Customers', IT refers to the area 'Information Technology', PR refers to the area 'Processes', RD refers to the area 'Research \& Development' and ST refers to the area 'Strategy'. 


\subsection{Hypotheses testing}

Table 3 presents the paired sample t-test for hypothesis 1 that states that a more than average level of IC disclosure in the prospectus results in a more than average level of IC disclosure in the subsequent annual report due to disclosure commitment. As hypothesized, the score for the prospectus is positive and significant at the 0.05 level. Company size also significantly influences the results. Since the limited amount of observations, the disconfirmation of auditor and age should be taken as a tentative conclusion. Industry affiliation is found to have a significant influence to the extent of IC disclosure.

Table 3: Linear regression

\begin{tabular}{|c|c|c|c|c|c|c|}
\hline \multirow[t]{2}{*}{ Mode } & & \multicolumn{2}{|c|}{ Unstandardized Coefficients } & \multirow{2}{*}{\begin{tabular}{|c|}
$\begin{array}{c}\text { Standardized } \\
\text { Coefficients }\end{array}$ \\
Beta
\end{tabular}} & \multirow[b]{2}{*}{$\mathrm{t}$} & \multirow[b]{2}{*}{ Sig. } \\
\hline & & B & Std. Error & & & \\
\hline \multirow[t]{10}{*}{1} & (Constant) & 34,678 & 12,759 & & 2,718 & 010 \\
\hline & SCORE Prospectus & 339 & 148 & 291 & 2,293 &, 027 \\
\hline & $\begin{array}{l}\text { Financial Services \& } \\
\text { Insurance }\end{array}$ & $-12,681$ & 6,773 & -273 & $-1,872$ &, 068 \\
\hline & $\begin{array}{l}\text { Industrial goods and } \\
\text { utilities }\end{array}$ & $-8,428$ & 4,745 & -230 & $-1,776$ & ,083 \\
\hline & Consumer goods & $-18,953$ & 5,085 & -487 & $-3,727$ & 001 \\
\hline & Chemicals &,- 407 & 5,143 &,- 010 &,- 079 &, 937 \\
\hline & Ownership retention & -261 & 117 & -240 & $-2,225$ & 032 \\
\hline & Big 4 Auditor & 2,403 & 3,542 &, 075 & 678 & 501 \\
\hline & Age $($ young $/$ old $)=18$ & 5,541 & 3,601 &, 164 & 1,539 & 132 \\
\hline & AR total asset & $5,003 E-9$ &, 000 &, 214 & 1,873 &, 068 \\
\hline
\end{tabular}

a. Dependent Variable: SCORE_AR

In order to find evidence for the second hypothesis, a one-way ANOVA was used (table 4). First, we look at the impact of the financial crisis on the difference in IC reporting in the prospectus. Companies were divided into two groups based on the year IPO (before or after 2008). The descriptive statistics indicate that the standard deviations of the observations in each group of similar magnitude. This also follows from the Levene's test of homogeneity of variances. Hence, the condition of equality of variance is satisfied. Hypothesis 2(a) is accepted whereas hypothesis 2(b) is not statistically significant at the 0.05 significance level.

Table 4: ANOVA table for IC disclosure by period

\begin{tabular}{|c|c|c|c|c|c|}
\hline \multicolumn{2}{|c|}{} & Sum of squares & $\mathrm{df}$ & $\mathrm{F}$ & Sig. \\
\hline SCORE_PROS & Between Groups & 1777.320 & 1 & 10.928 & 0.002 \\
& Within Groups & 10571.785 & 65 & & \\
& Total & 12349.104 & 66 & & \\
\hline SCORE_AR & Between groups & 60.737 & 1 & 0.245 & 0.623 \\
& Within groups & 13140.609 & 53 & & \\
& Total & 13201.345 & 54 & & \\
& & & & & \\
& &
\end{tabular}


Table 5 presents the paired sample t-test for hypothesis 3 that confirms that there exists a relationship between the amount of IC disclosure that a company reports in its prospectus and its annual report following to the IPO. On average the IC disclosure in the annual report is 10 units lower compared to the prospectus.

Table 5: Paired sample t-test

\begin{tabular}{|c|c|c|c|c|c|c|}
\hline & Mean & Std.Dev & St. Error mean & $\mathrm{t}$ & $\mathrm{df}$ & Sig. \\
\hline Pair 1 & 9.945 & 14.653 & 1.976 & 5.034 & 54 & 0.000 \\
\hline
\end{tabular}

\section{Conclusion}

The objective of this study is dual. On the one hand we want to determine the relationship between IC disclosure in the prospectus and the annual report and on the other hand we want to investigate the impact of the recent economic disturbance on the level of IC disclosure in the prospectus as well as the annual report. Each corporate document was manually scanned for IC information based on the index developed by Bukh et al (2004). The first hypothesis which states that a more than average level of IC disclosure in the prospectus results in a more than average level of IC disclosure in the subsequent annual report due to disclosure commitment.confirmed is confirmed. In the next research question we determined the impact of the recent economic disturbance on the level of IC disclosure in both prospectus and annual report. Only the prospectus was found to be influenced by the financial crisis. Lastly, we looked at the impact of the IC disclosure in the prospectus on the level of IC disclosure in the annual report. This impact is significant. 


\section{References}

Amir, E. and Lev, B. (1996), "Value-relevance of nonfinancial information: the wireless communication industry", Journal of Accounting and Economics, Vol 22, pp. 3-30.

Baker S.L., (2006), "Dummy variables (to represent categories) and time series", University of South Carolina.

Beattie, V. (1999) Business Reporting: The inevitable change, Institute of Chartered Accountants of Scotland, Edinburgh.

Beattie, V. and Thomson S.J. (2007), "Lifting the lid on the use of content analysis to investigate intellectual capital disclosures", Accounting Forum, Vol. 31, pp. 129-163.

Bontis, N. (2002), IC disclosures in Canadian Corporations, McMaster University, Hamilton.

Bozzolan, S., Favotto, F., and Ricceri, F. (2003), "Italian annual intellectual capital disclosure", Journal of Intellectual Capital, Vol. 4, No.4, pp. 543-558.

Brown, A., Osborn, T., Chan, J. and Jaganathan, V. (2005), "Managing intellectual capital", ResearchTechnology Managemement, Vol. 48, No. 6, pp. 34-41.

Brüggen, A., Vergauwen, P. and Dao, M., (2009), "Determinants of intellectual capital disclosure: evidence from Australia", Management Decision, Vol. 47, No. 2, pp. 233-245.

Bukh, P. (2003) "The relevance of IC disclosure: A paradox?", Accounting, Auditing and Accountability Journal, Vol. 16, No.1, pp. 49-56.

Bukh, P., Nielsen, C. and Gormsen, P. (2004) "Disclosure of information on intellectual capital in Danish IPO prospectuses", Accounting, Auditing \& Accountability Journal, Vol 18, No.6, pp. 713-732.

Chen, M., Cheng, S. and Hwang, Y. (2000) "An empirical investigation of the relationship between intellectual capital and firms' market value and financial performance”, Journal of Intellectual Capital, Vol. 6, No. 2, pp. 159-176.

Cooke, T. E., and Wallace, R. S. O. (1990) "Financial disclosure regulation and its environment: a review and further analysis", Journal of Accounting and Public Policy, Summer 1990.

Cordazzo, M. (2007). "Intangibles and Italian IPO prospectuses: a disclosure analysis", Journal of Intellectual Capital, Vol 8, No. 2, pp 288-305.

Clarkson, P.M., Ferguson, C. and Hall, J. (2003), "Auditor conservatism and voluntary disclosure: evidence from the year 200 systems issue", Accounting and Finance, Vol. 43, No.1, pp. 21-40.

Cumby, J. and Conrad, J. (2001) "Non-financial performance measures in the Canadian biotechnology industry", Journal of Intellectual Capital, Vol 2, No. 3, pp 261-272.

Daily, C.M., Certo, S.T., Dalton, D.R. and Roengpitya, R. (2003), "IPO underpricing: a meta-analysis and research synthesis", Entrepreneurship Theory and Practice, Vol. 27, No. 3, pp. 271-295.

Deegan, C. (2000) "Financial Accounting Theory”,, Mcgraw-Hill Book Company, Sydney.

Depoers, F. (2000) "A cost-benefit study of voluntary disclosure: some empirical evidence from French listed companies", The European Accounting Review, Vol 9, No. 2, pp. 245-263.

Holland, J. (2001) "Corporate value creation, intangibles, and valuation: a dynamic model of corporate value creation and disclosure", paper presented at the European Accounting Association Conference, Athens, 19 April. 
Jaggi, B. (1997), "Accuracy of forecast information disclosed in the IPO prospectuses of Hong Kong companies", The International Journal of Accounting, Vol. 32 No. 3, pp. 301-319.

Leuz, C. and Verrecchia, R.E. (2000), "The economic consequences of increased disclosure", Journal of Accounting Research, Vol. 38, Supplement: Studies on Accounting Information and the Economics of the Firm ,pp. 91-124

Lev, B. (2001) "Intangibles: management, measurement, and reporting", Brookings Institution Press, Washington, DC.

Lev, B. and Zambon, S. (2003), "Intangibles and intellectual capital: an introduction to a special issue", European Accounting Review, Vol. 12 No. 4, pp. 597-603

Mather, P., Ramsay, A. and Steen, A., (2000), "The use and representational faithfulness of graphs in Australian IPO prospectuses", Accounting, Auditing \& Accountability Journal, Vol. 13, No. 1, pp. 65-83.

Nielsen C., Bukh P.N., Mouritsen J., Johansen M.R., Gormsen P., (2006), "Intellectual capital statements on their way to the stock exchange", Journal of Intellectual Capital, Vol 7, No. 2, pp. 221-240.

Orens, R. and Derboven, J. (2008) "De rapportering van informatie over het intellectueel kapitaal in Belgische IPO-prospectussen", Accountancy en Bedrijfskunde, Vol. 7, pp. 16-31.

Petty, P. and Guthrie, J. (2000) "Intellectual capital literature review: measurement, reporting and management", Journal of Intellectual Capital, Vol 1, No. 2, pp. 155-75.

Singh I. and Van der Zahn M. (2008) "Determinants of intellectual capital disclosure in prospectuses of initial public offerings", Accounting and Business Research, Vol. 38, No. 5, pp. 409-431.

Sutthachai S. and Cooke T. E. (2009) "An analysis of Thai financial reporting practices and the impact of the 1997 economic crisis'", Journal of Accounting, Finance and Business Studies, Vol 45, No.4, pp. 492517.

Vandemale, S.N., Vergauwen P.G.M.C. and Smits A.J. (2005) "Intellectual capital disclosure in The Netherlands, Sweden and the UK: a longitudinal and comparative study", Journal of Intellectual Capital, Vol 6, No. 3, pp. 417-426.

Vergauwen P. and van Alem F. (2005) "Annual report IC disclosures in The Netherlands, France and Germany”, Journal of Intellectual Capital, Vol 6, No. 1, pp. 89-104. 